Institute and chairman of the board of Knox Theological College, Toronto. He was well known to many scientists in Britain and the United States. A recognized authority on low-temperature physics, he was equally at home with men and ideas. His bent for organization sprang from his imaginative grasp of problems outside his own field, his fresh and stimulating spirit, and his capacity for friendship. Always willing to attempt the difficult, he was devoted to the public welfare. His early death was a shock to his many colleagues and friends, a great loss to Canada and the community in which he lived.

In 1927 Prof. Wilhelm married Nan Kathleen Munro of Saskatoon. $\mathrm{He}$ is survived by his widow, a son Donald who is at present in England, and a daughter Mildred still attending school.

W. J. MACKeY

\section{Mrs. E. M. Reid}

Mrs. E. M. REID, the noted palæobotanist, died on September 28 in her ninety-third year. The daughter of John Copner Wynne Edwards, of Denbigh, she was educated at Westfield College, and taught mathematics at Cheltenham; she turned to geology and botany after her marriage to Clement Reid, of the Geological Survey, in 1897. Reid was a pioneer in the study of fossil fruits and seeds of the later geological formations, and Mrs. Reid threw herself wholeheartedly into this work, devising or improving techniques for extracting plant remains from peat, and bringing a methodical and highly critical intelligence to the study of the seeds and fruits so obtained. At that time it was by no means generally accepted that specific identifications were possible from isolated seeds and fruits, let alone from imperfect or fragmentary specimens which might have undergone alterations due to incipient fossilization. By a close study of the fruiting organs of living plants, however, the Reids proved conclusively that floral assemblages of the comparatively recent past could be reliably reconstructed from deposits which contained abundant fruits and seeds. Working backwards from Holocene and Pleistocene floras, their joint studies culminated in an extensive memoir on the "Pliocene Floras of the Dutch-Prussian Border" (1915). In 1916 Clement Reid died, only three years after retiring to Milford-on-Sea in Hampshire; his widow remained there for the rest of her life, and with great determination continued her palæobotanical research. She described preglacial floras from Durham, with an important "Comparative Review of Pliocene Floras" (1920), and from then on was constantly consulted-for determinations by botanists and geologists in various European countries.

After being joined by Miss M. E. J. Chandler, Mrs. Reid pressed her investigations farther back into the Tertiary, and in 1926 the British Museum (Natural History) published a volume by the two authors on the Bembridge (Oligocene) flora of the Isle of Wight, based on the a'Court Smith collection which had been acquired for the Geological Department of the Museum. Mrs. Rêd was then asked to study, in conjunction with Miss Chandler, the extensive collection of pyritized fruits and seeds from the Eocene London Clay, which had been in the British Museum for more than a century. Seven years intensive work produced the "London Clay Flora" (1933), which at once took its place as a classic of Tertiary palæobotany. In the introduction to these two monographs, and particularly the second, Mrs. Reid analysed with great lucidity the phytogeographical, climatic and evolutionary significance of the European floral succession throughout the Tertiary, as revealed by studies of angiospermous fruits and seeds. Certainty of identification depended on morphological and anatomical structure, which in turn threw light on secular changes of character within genera and families; biogeographical alliances of genera represented in fossil floras showed an increasing correlation in past Tertiary periods with present floras of the Far East, until finally the Eocene of southern England proved to have a tropical flora related to that of the present Indo-Malayan region.

After the work on the London Clay, Mrs. Reid undertook no major commitments, though she published a number of short papers either alone or with Miss Chandler, who lived with her and with whom she continued to discuss further studies on Tertiary floras of southern England. The final results of this prolonged research are now being prepared for publication by the Trustees of the British Museum.

Mrs. Reid and her husband lived most frugally; her life was strictly ordered with a disciplined austerity; she was critical but charming, and could always find time to assist other inquirers. She was devoted to her church and other local affairs, and found solace in reading, particularly books of travel. Her scientific work was the outcome of steady perseverance combined with originality and an analytical mind.

W. N. EDwards

\section{Dr. G. H. H. Tate}

Dr. George Henry Hamilon Tate, who died in Morristown, New Jersey, on Christmas Eve at the age of fifty-nine, was curator of mammals in the American Museum of Natural History, Now York.

Dr. Tate was born a British subject, on April 30, 1894, in London. He served in the Army during the First World War, and afterwards went to the United States, where, in 1921, he became a field assistant of the American Museum of Natural History. In 1927 he became an American citizen, and in the same year graduated as a bachelor of science of Columbia University, taking his master of arts degree in 1931. In the same year he was appointed assistant curator of South American mammals in the American Museum of Natural History, which post he held until 1942, when he was made associate curator of mammals, and later, in 1946, curator of mammals. In 1937 he was made a doctor of science in the University of Montreal. During the Second World War he served as chief of rubber explorations for the Defence Supplies Corporation at Washington.

During the course of his time at the American Museum, Dr. Tate went on forty-two collecting expeditions, to South America, New Guinea and Australia, as well as to West Africa. These expeditions, many of them carried out in association with Mr. Richard Archbold, led to an imposing series of monographs, those on the Chiroptera, Rodentia and Marsupialia being of particular importance.

Dr. Tate came fairly regularly to England, where his mother still lives, and his work brought him for weeks at a time to the British Museum (Natural History), where the staff of the Mammal Room were always glad to welcome him, together with his wife Eleanor who survives him.

T. C. S. MorRISON-SCOTT 